\title{
Effect of SOS-induced Pol II, Pol IV, and Pol V DNA polymerases on UV-induced mutagenesis and MFD repair in Escherichia coli cells
}

\author{
Michał Wrzesiński, Anetta Nowosielska, Jadwiga Nieminuszczy and \\ Elżbieta Grzesiuk ${ }^{凶}$
}

\section{Institute of Biochemistry and Biophysics, Polish Academy of Sciences, Warszawa, Poland}

Received: 29 December, 2004; accepted: 12 March, 2005

Key words: $E$. coli, UV induced mutagenesis, MFD, mutD5, umuDC, $\operatorname{din} B, \operatorname{polB}$

\begin{abstract}
Irradiation of organisms with UV light produces genotoxic and mutagenic lesions in DNA. Replication through these lesions (translesion DNA synthesis, TSL) in Escherichia coli requires polymerase V (Pol V) and polymerase III (Pol III) holoenzyme. However, some evidence indicates that in the absence of Pol V, and with Pol III inactivated in its proofreading activity by the mutD5 mutation, efficient TSL takes place. The aim of this work was to estimate the involvement of SOS-inducible DNA polymerases, Pol II, Pol IV and Pol V, in UV mutagenesis and in mutation frequency decline (MFD), a mechanism of repair of UV-induced damage to DNA under conditions of arrested protein synthesis. Using the $\arg E 3 \rightarrow \mathrm{Arg}^{+}$reversion to prototrophy system in E. coli $\mathrm{AB1157}$, we found that the umuDC-encoded Pol V is the only SOS-inducible polymerase required for UV mutagenesis, since in its absence the level of $\mathrm{Arg}^{+}$revertants is extremely low and independent of Pol II and/or Pol IV. The low level of UV-induced $\mathrm{Arg}^{+}$revertants observed in the AB1157mutD5 $\triangle$ umuDC strain indicates that under conditions of disturbed proofreading activity of Pol III and lack of Pol V, UV-induced lesions are bypassed without inducing mutations. The presented results also indicate that Pol V may provide substrates for MFD repair; moreover, we suggest that only those DNA lesions which result from umuDC-directed UV mutagenesis are subject to MFD repair.
\end{abstract}

Irradiation of organisms with UV light produces lesions in DNA that stop replication.
The two primary UV induced lesions in DNA are cis,syn-cyclobutane pyrimidine dimers

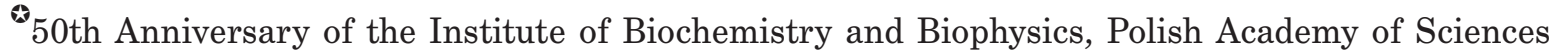

${ }^{\square}$ Correspondence to: E. Grzesiuk, Institute of Biochemistry and Biophysics, Polish Academy of Sciences, A. Pawiñnskiego 5A, 02-106 Warszawa, Poland; fax: (48) 3912 1623; e-mail: elag@ibb.waw.pl Abbreviations: CPD, cyclobutane pyrimidine dimer; MFD, mutation frequency decline; Pol, DNA polymerase; TSL, translesion DNA synthesis.
} 
(CPD) and the pyrimidine (6-4) pyrimidone photoproducts formed at a ratio of 3:1 at moderate doses of UV (Mitchell \& Nairn, 1989).

Several observations indicate that translesion DNA synthesis (TSL) past CPD is almost entirely dependent on the activity of DNA polymerase V (Pol V) encoded by the umuDC operon (Szekeres et al., 1996; Vendewiele et al., 1998). However, efficient TSL has also been observed after SOS-induction in strains with $u m u D C$ deletion, if these strains were deficient in the $3^{\prime} \rightarrow 5^{\prime}$ exonuclease proofreading activity of DNA polymerase III (Pol III) (Vendewiele et al., 1998; Borden et $a l ., 2002)$. The proofreading function is ensured by the $\varepsilon$ subunit of Pol III and is inactivated by the mutD5 mutation in $\operatorname{dnaQ}$ gene (Takano et al., 1986). Deprivation of the proofreading activity leads to a large increase in spontaneous mutations, chronic induction of SOS response (Nowosielska et al., 2004a; 2004b; Janion et al., 2002), and expression of over 40 genes, among them $\operatorname{pol} B$, $\operatorname{din} B$, and umuDC, encoding repair polymerases Pol II, Pol IV, and Pol V, respectively (Friedberg et al., 1995; Tang et al., 1999; Janion, 2001). A common feature of the SOS-inducible DNA polymerases is their ability to replicate past a non-instructive lesion (Szekeres et al., 1996; Napolitano et al., 2000). Participation of a particular polymerase in TSL depends on the sequence and type of damage that blocks DNA replication (Wagner et al., 1999; 2002; Napolitano et al., 2000).

In this work we studied the contribution of Pol III, the main replication polymerase of E. coli, and of SOS-inducible repair polymerases, Pol II, Pol IV, and Pol V, to UV mutagenesis and to mutation frequency decline (MFD) repair. MFD is a loss of certain UV-induced tRNA suppressor mutations under conditions of transient inhibition of protein synthesis immediately following UV irradiation (Witkin, 1956; 1994; Doudney \& Haas, 1958; Selby \& Sancar, 1994). This phenomenon is connected with an error-free repair system preferentially acting on the transcribed strand of DNA. Encoded by the $m f d$ gene, the Mfd protein is a transcription repair coupling factor (TRCF) (Selby \& Sancar, 1991) that frees DNA from RNA polymerase stalled at the damage site and directs repair proteins to the transcribed DNA strand.

We found that (i) the $u m u D C$-encoded Pol V is indispensable to UV mutagenesis; (ii) the SOS-inducible Pol II and Pol IV are not involved in UV mutagenesis; (iii) in a strain deficient in Pol V and mutated in proofreading Pol III the level of UV-induced $\mathrm{Arg}^{+}$revertants is low which may indicate a more precise bypass of UV-induced lesions by mutated Pol III than by Pol V; (IV) UV-irradiated and transiently starved $E$. coli cells are subject to MFD but only in strains proficient in Pol V.

\section{MATERIALS AND METHODS}

Bacterial strains and plasmids. The E. coli strains and plasmids used in this study are listed in Table 1. Strains RW82, NR9458, YG7207, and NR11501 were donors of the $\triangle u m u D C, m u t D 5, \Delta d i n B$, and $\triangle$ polB markers, respectively. The remaining strains were constructed according to Miller (1972) by P1-mediated transduction of the desired gene into the recipient $\mathrm{AB} 1157$ strain and its $m u t D 5$ derivative. Bacteria were selected on LB plates containing the appropriate antibiotic: $50 \mu \mathrm{g} /$ $\mathrm{ml}$ kanamycin or spectinomycin, $30 \mu \mathrm{g} / \mathrm{ml}$ chloramphenicol, or $12.5 \mu \mathrm{g} / \mathrm{ml}$ tetracycline.

Media and plates. LB (Luria-Bertani) medium contained $1 \%$ Bacto-tryptone, $0.5 \%$ yeast extract and $0.5 \% \mathrm{NaCl}$. The $\mathrm{E}$ medium consisted of C-salts (Vogel \& Bonner, 1956) supplemented with $0.5 \%$ glucose, $0.2 \%$ casamino acids, $10 \mu \mathrm{g} / \mathrm{ml}$ thiamine, and $25 \mu \mathrm{g} / \mathrm{ml}$ each of arginine, histidine, threonine, proline, and leucine. E-Arg medium was E medium deprived of arginine. For starvation bacteria were incubated in C-salts supplemented with $0.5 \%$ glucose. Plates were solidified with $1.5 \%$ Difco agar. 
UV treatment and MFD assay. Overnight bacterial cultures in LB were diluted 1:50 in LB-medium, grown to a density of $2-4 \times 10^{8}$ cells $/ \mathrm{ml}$ at $37^{\circ} \mathrm{C}$ with shaking, centrifuged, and resuspended in C-salts. Samples of $5 \mathrm{ml}$ were irradiated for $35 \mathrm{~s}$ in Petri plates $(\phi 80 \mathrm{~mm})$ with a Philips $15 \mathrm{~W}$ UV lamp, placed $8 \mathrm{~cm}$ above the plate, emitting mainly $254 \mathrm{~nm}$ light. The UV dose was $45 \mathrm{~J} / \mathrm{m}^{2}$ except for the AB1157 mfd-1uvrA6 strain which was irradiated with $2.7 \mathrm{~J} / \mathrm{m}^{2}$ and the UV lamp was placed $16 \mathrm{~cm}$ above the plate. Before and after irradiation, samples were withdrawn to estimate the number of viable cells. The irradiated bacteria were diluted 10-fold in LB medium either immediately or after further incubation (usually for $20 \mathrm{~min}$ ) in C salts supplemented with $0.5 \%$ glucose (starvation conditions), then incubated overnight and plated on LB for viable cells and E-Arg for $\mathrm{Arg}^{+}$counts. Viable cells were counted after one day of incubation, whereas $\mathrm{Arg}^{+}$colonies required 2 days to be well visible. The frequency of UV-induced $\operatorname{argE} 3 \rightarrow \mathrm{Arg}^{+}$revertants per viable cells was then calculated.

Table1. Bacterial strains

\begin{tabular}{|c|c|c|}
\hline Strain & Genotype & Origin \\
\hline AB1157 & $\begin{array}{l}\text { thr-1 ara-14 leuB6 } \Delta \text { (gpt-proA)62 lacY1 tsx-33 supE44 amber galK2 } \\
\text { hisG4 rfbD1 mgl-51 rpsL31 kdgK51 xyl-5 mtl-1 argE3 thi-1 }\end{array}$ & Bachmann (1987) \\
\hline NR9458 & mutD5 zaf-13::Tn10 ara thi $\Delta($ prolac $)$ & $\begin{array}{l}\text { Schaaper \& Cornacchio } \\
\text { (1992) }\end{array}$ \\
\hline YG7207 & $\Delta(\operatorname{din} B-y a f N):: k a n$ derivative of $\mathrm{AB} 1157$ & $\begin{array}{l}\text { Kim et al. (1997); } \\
\text { McKenzie et al. (2003) }\end{array}$ \\
\hline RW82 & $\triangle u m u D C 595::$ cat derivative of $\mathrm{AB} 1157$ but thyA325 & Woodgate (1992) \\
\hline NR11501 & $\Delta$ polB::spc::str ara thi $\Delta($ prolac $)$ derivative of KA796 & Escarceller et al. (1994) \\
\hline EC2413 & AB1157 but $\triangle u m u D C 595:: c a t$ & Grzesiuk \& Janion (1994) \\
\hline EC2426 & $\mathrm{AB} 1157 m f d-1$ & $\begin{array}{l}\text { Grzesiuk E. (Fabisiewicz \& } \\
\text { Janion, 1998) }\end{array}$ \\
\hline $\mathrm{EC} 2424$ & AB1157 (mfd-1, uvrA6::Tn10) & $\begin{array}{l}\text { Wójcik A. (Fabisiewicz \& } \\
\text { Janion, 1998) }\end{array}$ \\
\hline AN20 & AB1157 but mutD5 zaf13::Tn10 & Nowosielska et al. (2004a) \\
\hline AN21 & AB1157 but mutD5 zaf13::Tn10 $\Delta u m u D C 595:: c a t$ & Nowosielska et al. (2004a) \\
\hline AN22 & AB1157 but mutD5 zaf13::Tn10 $\Delta$ dinB::kan & Nowosielska et al. (2004a) \\
\hline AN23 & AB1157 but mutD5 zaf13::Tn10 $\Delta u m u D C 595:: c a t \Delta d i n B:: k a n$ & Nowosielska et al. (2004a) \\
\hline AN24 & AB1157 but mutD5 zaf13::Tn10. $\Delta$ polB::spc::str) & Nowosielska et al. (2004a) \\
\hline AN26 & $\begin{array}{l}\text { AB1157 but mutD5 zaf13::Tn10 } \Delta u m u D C 595:: c a t \Delta d i n B:: k a n \\
\text { ApolB::spc::str }\end{array}$ & Nowosielska et al. (2004a) \\
\hline WN1 & AB1157 but $\Delta$ dinB::kan & this work \\
\hline WN2 & AB1157 but $\Delta p o l B:: s p c:: s t r$ & this work \\
\hline WN3 & AB1157 but $\Delta u m u D C 595:: c a t \Delta d i n B:: k a n$ & this work \\
\hline WN4 & AB1157 but $\Delta u m u D C 595::$ cat $\Delta$ dinB::kan $\Delta$ polB::spc::str & this work \\
\hline WN5 & AB1157 but $\Delta$ dinB::kan $\Delta$ polB::spc::str & this work \\
\hline WN6 & AB1157 but mutD5 zaf13::Tn10 $\Delta$ dinB::kan $\Delta$ polB::spc::str & this work \\
\hline WN7 & AB1157 but mutD5 zaf13::Tn10 $\Delta u m u D C 595:: c a t \Delta p o l B:: s p c:: s t r$ & this work \\
\hline WN8 & AB1157 but $\triangle$ umuDC595::cat $\Delta$ dinB::kan $\Delta$ polB::spc::str pYG768 & this work \\
\hline WN9 & AB1157 but $\Delta u m u D C 595::$ cat $\Delta$ dinB::kan $\Delta$ polB::spc::str pGW2123 & this work \\
\hline
\end{tabular}


Experiments on separate cultures were repeated 4-6 times, each in duplicate, and the standard deviations (S.D.) were estimated. All plates were incubated at $37^{\circ} \mathrm{C}$.

\section{RESULTS}

\section{Survival of E. coli AB1157 derivatives af- ter UV irradiation}

The sensitivity of strains used in this study, described as the percentage of survival, to $\mathrm{UV}_{254}$ irradiation is shown in Table 2. AB1157 strains bearing a single mutation in genes encoding DNA polymerases Pol III, Pol II or Pol IV showed a sensitivity to UV irradiation similar to that of AB1157 wt. However, deletion of the $u m u D C$ operon encoding Pol V led to a noticeable increase in the sensitivity to UV irradiation in all the strains tested, including those lacking Pol II (polB deletion), Pol IV (dinB deletion), and mutated in the $\varepsilon$ subunit of Pol III (mutD5). For four strains, AB1157 wt and three of its derivatives, $\triangle u m u D C$, mutD5, and mutD5 $\Delta u m u D C$, sensitivity to various doses of $\mathrm{UV}_{254}$ was estimated (Fig. 1A). The introduction of the mutD5 mutation led to a decreased sensitivity to UV irradiation, whereas, as already men-

Table 2. Survival and frequency of $\mathrm{Arg}^{+}$revertants in $E$. coli AB1157 derivatives after UV irradiation $\left(2.7 \mathrm{~J} / \mathrm{m}^{2}\right.$ for the $m f d-1$ uvrA6 mutant and $45 \mathrm{~J} / \mathrm{m}^{2}$ for other strains)

\begin{tabular}{|c|c|c|c|c|}
\hline Strain & $\begin{array}{l}\text { Survival (\%) } \\
\text { after UV } \\
\text { irradiation }\end{array}$ & $\begin{array}{l}\text { Spontaneous Arg } \\
\text { revertants } / 10^{8} \\
\text { cells }\end{array}$ & $\begin{array}{l}\text { UV-induced } \mathrm{Arg}^{+} \\
\text {revertants } / 10^{8} \\
\text { cells }\end{array}$ & $\begin{array}{l}\text { UV-induced } \mathrm{Arg}^{+} \text {rever- } \\
\text { tants } / 10^{8} \text { cells in cultures } \\
\text { starved for } 20 \mathrm{~min}\end{array}$ \\
\hline wt & $26.3 \pm 9.5$ & $10.9 \pm 6.6$ & $2242.3 \pm 325.6$ & $259.3 \pm 73.7$ \\
\hline$m f d-1$ & $13.9 \pm 6.1$ & $5.1 \pm 0.5$ & $1283.3 \pm 72.7$ & $643.0 \pm 162.2$ \\
\hline$m f d-1$ uvrA6 & $21.2 \pm 3.2$ & $13.6 \pm 2.5$ & $340.0 \pm 56.4$ & $315.7 \pm 75.7$ \\
\hline$\triangle u m u D C$ & $11.4 \pm 5$ & $4.1 \pm 1.6$ & $1.1 \pm 0.5$ & $1.9 \pm 1.0$ \\
\hline$\Delta p o l B$ & $23.1 \pm 16.3$ & $5.4 \pm 1$ & $2440.0 \pm 62.6$ & $347.7 \pm 19.1$ \\
\hline$\Delta \operatorname{din} B$ & $36.7 \pm 3.7$ & $52.9 \pm 30.5$ & $1815.0 \pm 144.0$ & $431.7 \pm 203.8$ \\
\hline$\Delta \operatorname{din} B \Delta p o l B$ & $46.3 \pm 5.9$ & $6.0 \pm 2.3$ & $3750.0 \pm 284.0$ & $331.5 \pm 293.4$ \\
\hline$\triangle u m u D C \Delta \operatorname{din} B$ & $3.2 \pm 0.7$ & $1.8 \pm 0.2$ & $1.3 \pm 0.2$ & $0.9 \pm 0.2$ \\
\hline$\triangle u m u D C \Delta \operatorname{din} B \Delta p o l B$ & $2.8 \pm 1.6$ & $4.4 \pm 1.5$ & $10.7 \pm 3.2$ & $1.6 \pm 0.8$ \\
\hline $\begin{array}{l}\triangle u m u D C \triangle \operatorname{din} B \triangle p o l B \\
\text { pYG768 }\end{array}$ & $7.8 \pm 5.1$ & $2.2 \pm 0.8$ & $11.9 \pm 1.9$ & $2.0 \pm 0.1$ \\
\hline$\triangle u m u D C$ pGW2123 & $54.7 \pm 7.3$ & $28.7 \pm 2.3$ & $2810.0 \pm 358.4$ & $618.3 \pm 105.9$ \\
\hline $\begin{array}{l}\triangle u m u D C \Delta \operatorname{din} B \triangle p o l B \\
\text { pGW2123 }\end{array}$ & $24.7 \pm 10.3$ & $20.5 \pm 4.6$ & $3069.3 \pm 711.1$ & $285.3 \pm 45.1$ \\
\hline mutD5 & $58.2 \pm 9.1$ & $357.6 \pm 42.1$ & $2732.2 \pm 123.4$ & $944.7 \pm 131.5$ \\
\hline mutD5 $\triangle u m u D C$ & $7.1 \pm 5.1$ & $115.2 \pm 36.9$ & $351.3 \pm 114.4$ & $210.7 \pm 34.1$ \\
\hline mutD5 $\Delta \operatorname{din} B$ & $14.0 \pm 5.8$ & $70.3 \pm 19.7$ & $1538.0 \pm 182.1$ & $405.0 \pm 140.8$ \\
\hline mutD5 $\Delta p o l B$ & $20.2 \pm 2.3$ & $146.0 \pm 13.9$ & $2720.0 \pm 161.7$ & $497.0 \pm 63.2$ \\
\hline $\begin{array}{l}\text { mutD5 } \triangle u m u D C \\
\Delta d i n B\end{array}$ & $6.9 \pm 4.1$ & $219.8 \pm 47$ & $223.0 \pm 39.1$ & $184.3 \pm 26.2$ \\
\hline mutD5 $\triangle u m u D C \triangle p o l B$ & $4.3 \pm 0.3$ & $72.9 \pm 26.1$ & $401.3 \pm 97.1$ & $121.8 \pm 34.2$ \\
\hline mutD5 $\Delta \operatorname{din} B \Delta p o l B$ & $41.7 \pm 1.7$ & $73.6 \pm 14.0$ & $1985.5 \pm 129.0$ & $64.7 \pm 7.2$ \\
\hline $\begin{array}{l}\text { mutD5 } \triangle \text { umuDC } \\
\Delta \text { dinB } \Delta \text { polB }\end{array}$ & $31.3 \pm 2.1$ & $92.8 \pm 20.2$ & $194.0 \pm 43.3$ & $147.5 \pm 27.3$ \\
\hline
\end{tabular}


tioned, additional deletion of the $u m u D C$ operon sensitised the cells to UV light.

Single mutation in the $m f d$ gene did not influence the sensitivity of the AB1157 strain to

A

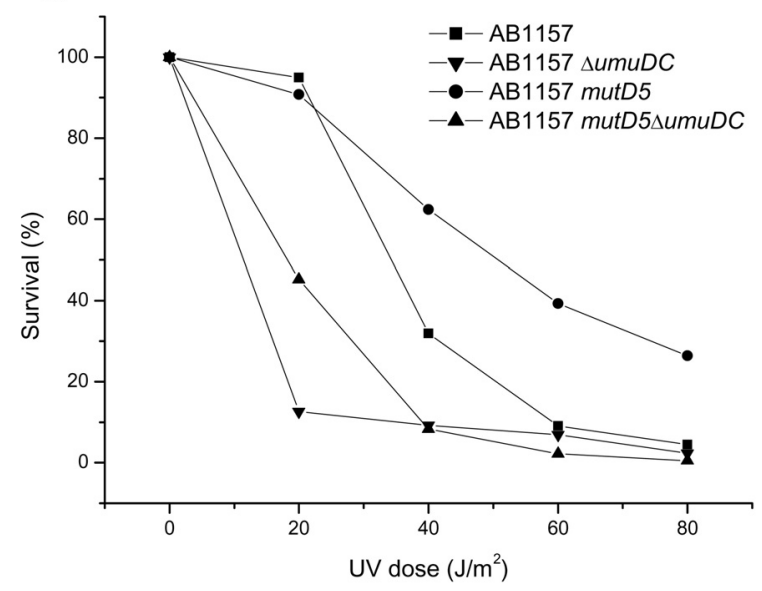

among all strains tested, even in the mutD5, only those with the $u m u D C$ deletion showed a low level of UV-induced mutations. Thus, the results in Table 2 indicate that the only poly-

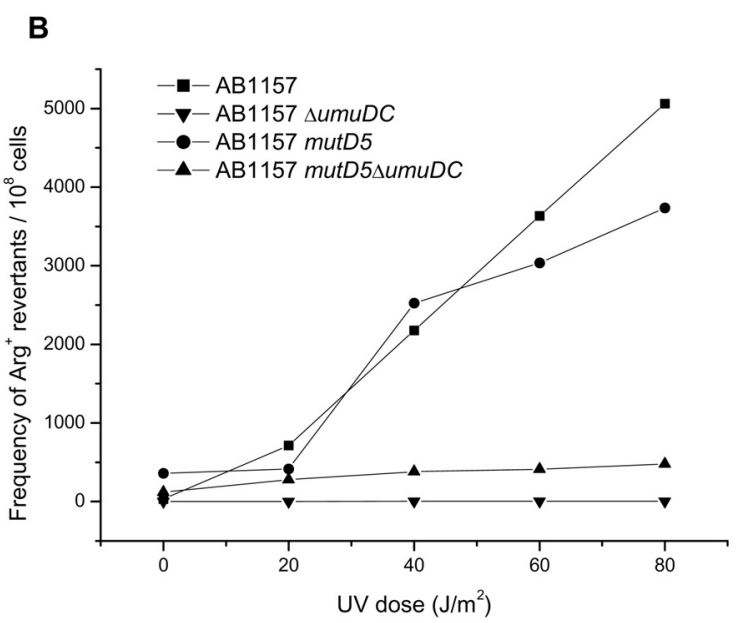

Figure 1. (A) survival and (B) $\operatorname{argEB} \rightarrow \mathrm{Arg}^{+}$reversion frequency in UV-irradiated AB1157 strains.

The data points shown are the averages of 4-6 independent experiments, each performed in duplicate. S.D. value was $1-10 \%$.

UV irradiation, however, the double mutant $m f d-1$ uvrA6 was extremely sensitive to UV light and therefore in further experiments had to be irradiated with an about 17 -fold lower dose $\left(2.7 \mathrm{~J} / \mathrm{m}^{2}\right)$ than the other strains.

\section{UV-induced $\operatorname{argES} \rightarrow \mathrm{Arg}^{+}$reversion fre- quency in AB1157 mutD5 strains deficient in Pol II, Pol IV or Pol V polymerases}

The studies were performed on AB1157 strains bearing an ochre mutation in the $\operatorname{argE3}$ locus. Only $\operatorname{argE3} \rightarrow \mathrm{Arg}^{+}$reversion allows growth of these bacteria on a minimal medium without arginine. Table 2 shows frequencies of UV-induced $\mathrm{Arg}^{+}$reversion in the AB1157 strain and its mutD5 derivative mutated in the $\varepsilon$ subunit of Pol III. It also includes the frequencies of $\mathrm{Arg}^{+}$reversion in strains deleted in the polB, $\operatorname{din} B$, and $u m u D C$ genes encoding Pol II, Pol IV and Pol V, respectively. The presence of the mutD5 allele led to an increased level of spontaneous $\mathrm{Arg}^{+}$ revertants but a level of UV-induced $\mathrm{Arg}^{+}$ revertants in mutD5 strain was comparable to that in the $m u t D^{+}$background. However, merase essential for UV mutagenesis is Pol V. This conclusion is confirmed by application of different doses of UV to four strains, AB1157, $\triangle u m u D C$, mutD5, and mutD5 $\Delta u m u D C$, and estimation of the frequency of $\mathrm{Arg}^{+}$revertants (Fig. 1B). In both $u m u D C^{+}$strains a dose dependent increase in UV induced $\mathrm{Arg}^{+}$ revertants was observed. In strains lacking the $u m u D C$ genes, the level of $\mathrm{Arg}^{+}$revertants remained low (in mutD5 $5 u m u D C$ ) or extremely low (in $\triangle u m u D C$ ), independently of the UV dose.

Additional proof for the dependency of UV mutagenesis on Pol V was provided by results obtained in the AB1157 4 umuDC strain harbouring the pGW2123 plasmid overproducing $\mathrm{UmuD}^{\prime} \mathrm{C}$ proteins. In this strain the presence of Pol V of plasmid origin led to a significant increase in the frequency of UV-induced $\mathrm{Arg}^{+}$revertants equalling or even outnumbering the level of such revertants in the AB1157umuDC ${ }^{+}$strain (Table 2, column 4, rows 2 and 12) which was not observed in a strain bearing the pYG768 plasmid overproducing Pol IV polymerase (Table 2, column 4, row 11). 
Mutation frequency decline (MFD) in strains mutated in the $\varepsilon$ subunit of Pol III and deficient or proficient in polymerases Pol II, Pol IV or Pol V

In order to evaluate the role of Pol II, Pol IV, Pol V, and the proofreading $\varepsilon$ subunit of Pol III in the MFD type of DNA repair, the level of UV-induced $\mathrm{Arg}^{+}$revertants was estimated in transiently starved polB, $\operatorname{din} B$, umuDC, and mutD5 mutants. After UV-irradiation at a dose of $45 \mathrm{~J} / \mathrm{m}^{2}, \mathrm{AB} 1157$ cells were incubated for $20 \mathrm{~min}$ in C-salts supplemented with glucose but not with the amino acids required for growth (starvation conditions). To express the mutations, further incubation was in the LB medium. The frequencies of spontaneous and UV-induced $\mathrm{Arg}^{+}$revertants in the listed AB1157 derivatives are shown in Table 2, columns 3 and 4 . Column 5 contains frequencies of UV-induced $\mathrm{Arg}^{+}$revertants in samples starved prior to further incubation in the complete medium. High rates of MFD (7- to 30 -fold decline in the frequency of UV-induced $\mathrm{Arg}^{+}$revertants after transient starvation) were observed for the wt strain and four of its derivatives, mutD $5 \Delta \operatorname{din} B \Delta p o l B$, $\triangle \operatorname{din} B \Delta$ polB, $\triangle p o l B$, and $\triangle u m u D C \Delta \operatorname{din} B \Delta p o l B$ bearing the pGW2123 plasmid overproducing $\mathrm{UmuD}^{\prime} \mathrm{C}$ proteins (Pol V). In contrast, all the strains lacking Pol V ( $\triangle u m u D C)$ did not show any decline in the frequency of UV-induced $\mathrm{Arg}^{+}$revertants after transient starvation. These two sets of data may suggest an at least indirect involvement of Pol V in MFD repair. The most spectacular result, a 30-fold decline in the frequency of UV-induced $\mathrm{Arg}^{+}$revertants after $20 \mathrm{~min}$ of starvation in the mutD5 $\Delta$ dinB $\Delta$ polB strain may indicate better access of Pol V to DNA lesions in the absence of Pol IV and Pol II.

For the wt strain and its five derivatives, $\Delta u m u D C$, mutD5, mutD5 $\Delta$ polB, mutD5 $\Delta$ dinB, and mutD5 $\Delta u m u D C, \mathrm{Arg}^{+}$reversion frequencies were determined at different times of starvation to estimate the kinetics of MFD repair (Fig. 2). The data indicate that a decline in mutation frequency takes place in the wt and

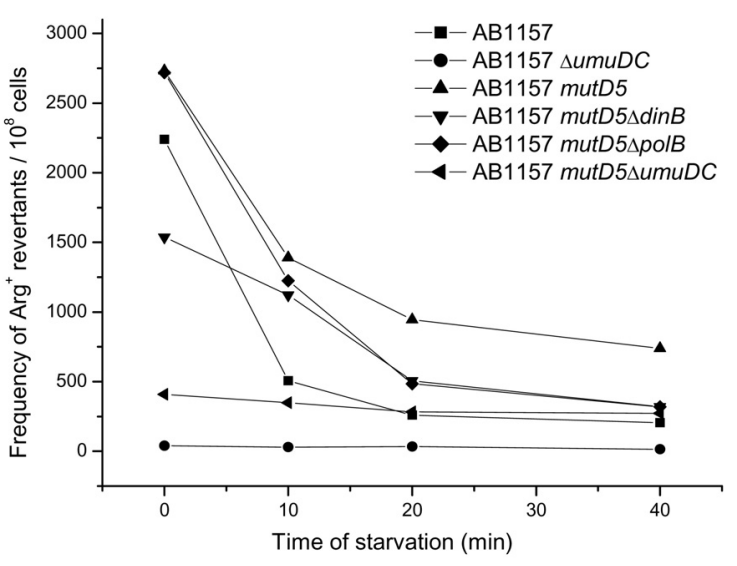

Figure 2. Effect of defect in the $\varepsilon$ subunit of Pol III (the mutD5 mutation) and the umuDC deletion on kinetics of MFD in UV-irradiated and starved for indicated time AB1157 strains.

The data points shown are the averages of 4-6 independent experiments, each performed in duplicate. S.D. value was $1-10 \%$.

mutD5 $\Delta$ polB strains, is less visible in the mutD5 and mutD5 $\Delta$ dinB ones, and absent in the strain with deleted $u m u D C$ genes. We suggest that in the mutD5 background, MFD repair is less visible, being masked by mutations resulting from damage in the proofreading function of Pol III. These mutations are probably not subject to MFD.

\section{DISCUSSION}

In this work we investigated UV-induced mutagenesis in $E$. coli strains deficient in the $3^{\prime} \rightarrow 5^{\prime}$ exonucleolytic proofreading activity ensured by the $\varepsilon$ subunit of the replicative polymerase Pol III, and defective in the SOS-induced DNA polymerases Pol II, Pol IV, and Pol V. We also examined the contribution of these polymerases to MFD repair, connected with transcription. The test system used was chromosomal $\operatorname{argE} 3 \rightarrow \mathrm{Arg}^{+}$reversion to prototrophy in $E$. coli AB1157 strains. Only a back mutation at the $\operatorname{argE} 3$ locus or tRNA suppressor formation leading to $\mathrm{Arg}^{+}$ phenotype allows for growth of these cells on minimal medium deprived of arginine (Śledziewska-Gójska et al., 1992). 
There is strong evidence that TLS past UV-induced $\mathrm{CPD}$ requires $E$. coli $\mathrm{UmuD}_{2}{ }_{2} \mathrm{C}$ proteins (Friedberg et al., 1995; Gonzalez \& Woodgate, 2001; Goodman \& Woodgate, 2000; Sutton \& Walker, 2001; Sutton et al., 2001), known as SOS-inducible mutagenic DNA polymerase Pol V (Reuven et al., 1999; Tang et al., 1999). Our observations confirmed that almost all the UV-induced $\mathrm{Arg}^{+}$ revertants were Pol V dependent. The tested strains, regardless of whether Pol II and Pol IV were present or absent, did not show UV mutagenesis in the absence of Pol V. In the strains bearing the high copy number plasmid pGW2123, producing numerous copies of the $\mathrm{UmuD}_{2}{ }_{2} \mathrm{C}$ proteins, the level of UV-induced $\mathrm{Arg}^{+}$revertants was slightly higher compared to the plasmid-free strain containing Pol V of chromosomal origin independently of the presence of Pol II or Pol IV. Introduction of the pYG768 plasmid producing Pol IV into the $A B 1157 \Delta u m u D C \Delta \operatorname{din} B \Delta$ polB strain preserved UV mutagenesis at the same extremely low level as in the strain without the plasmid.

Pol III, the main replicative polymerase, demonstrates the high accuracy of replication and usually involves replication of undamaged templates. However, it has been found that in the absence of the $3^{\prime} \rightarrow 5^{\prime}$ exonucleolytic proofreading activity encoded by the $\varepsilon$ subunit, $\mathrm{Pol}$ III can bypass CPD similarly to Pol V (Borden et al., 2002). The observed almost 8-fold lower frequency of $\mathrm{Arg}^{+}$revertants in the $\mathrm{AB} 1157 m u t D 5 \Delta u m u D C$ strain than in AB1157mutD5 seems to confirm this finding, suggesting more precise TSL by Pol III mutated in its proofreading function compared to a properly functioning Pol V. Another explanation is that in the absence of Pol V, less TLS occurs and so lesions are repaired prior to replication.

Transcription and DNA repair are coupled in $E$. coli by the Mfd protein which dissociates transcription elongation complexes blocked at non-pairing lesions such as CPD. Decline in mutation frequency, i.e., the MFD phenomenon, can be observed in UV-irradiated and transiently starved E. coli cells (Witkin, 1994). In our experiments, an 8.6-fold decline in the frequency of UV-induced $\mathrm{Arg}^{+}$revertants was observed in AB1157 wt strain, 2-fold in $\mathrm{AB} 1157 m f d 1$ strain, and none in AB1157mfd1uvrA6 strain mutated in both MFD and nucleotide excision repair. The occurrence of MFD in the $\mathrm{AB} 1157 \Delta u m u D C$ strain was impossible to estimate, since the level of UV-induced $\mathrm{Arg}^{+}$revertants was extremely low. However, in the AB1157 $\triangle u m u D C$ strain harbouring pGW2123, a plasmid encoding $\mathrm{UmuD}^{\prime} \mathrm{C}$ proteins, a high level of UV-induced $\mathrm{Arg}^{+}$revertants but only a 4.5 -fold decline in their frequency after starvation were seen. Surprisingly, in $\mathrm{AB} 1157 \Delta u m u D C \Delta \operatorname{din} B \Delta$ polB bearing pGW2123 not only a high level of UV-induced $\mathrm{Arg}^{+}$revertants but also an intense MFD (11-fold decline in mutation frequency) were observed. The intensity of MFD in this strain can be explained by creation of more mismatches during TLS that serve as substrates for MFD-related repair. A better access of an elevated number of Pol V molecules to UV-induced DNA lesions in the absence of Pol II and Pol IV may also be taken into consideration.

Among all the strains tested the highest rate (over 30-fold) of decline of $\mathrm{Arg}^{+}$revertants in UV-irradiated and starved cultures was observed in the case of the mutD5 $\Delta \operatorname{din} B \Delta$ polB strain. Interestingly, the strain deleted for $\operatorname{din} B$ and polB but with a properly functioning proofreading activity of Pol III has shown an only 11-fold decline of such revertants. Thus, in E. coli cells lacking Pol IV and Pol II, and mutated in the $\varepsilon$ subunit of Pol III, Pol V seems to be a very efficient support of MFDrelated repair.

\section{R E F E R E N C E S}

Bachmann BJ. (1987) Derivations and genotypes of some mutant derivatives of Escherichia coli K-12, In Escherichia coli and Salmonella typhimurium: Cellular and Molecular Biology. Neidhardt FC, Ingraham J, Low KB, 
Magasanik B, Schaechler M, Umbarger HE, eds, vol 2, pp 1190-219, AMS Press, Washington D.C.

Borden A, O’Grady PI, Vendeviele D, Fernandez de Henestrosa AR, Lawrence CW, Woodgate R. (2002) Escherichia coli DNA polymerase III can replicate efficiently past a T-T cis-syn cyclobutane dimer if DNA polymerase $\mathrm{V}$ and the $3^{\prime}$ to $5^{\prime}$ exonuclease proofreading function encoded by $d n a Q$ are inactivated. $J$ Bacteriol.; 184: 2674-81.

Doudney CO, Haas FL. (1958) Modification of ultraviolet induced mutation frequency and survival in bacteria by post-irradiation treatment. Proc Natl Acad Sci USA.; 44: 390-8.

Escarceller M, Hicks J, Godmundsson G, Trump G, Touati D, Lovett S, Foster PL, McEntee K, Goodman MF. (1994) Involvement of Escherichia coli DNA polymerase II in response to oxidative damage and adaptive mutation. $J$ Bacteriol.; 176: 6221-18.

Fabisiewicz A, Janion C. (1998) DNA mutagenesis and repair in UV-irradiated $E$. coli K-12 under condition of mutation frequency decline. Mutat Res.; 402: 59-66.

Friedberg EC, Walker GC, Siede W. (1995) SOS response and DNA damage tolerance in Procaryotes. In DNA Repair and Mutagenesis. Friedberg EC, Walker GC, Siede W. eds, pp 407-34, ASM Press, Washington, D.C.

Gonzalez M, Woodgate R. (2001) The "tale" of UmuD and its role in SOS mutagenesis. BioEssays.; 24: 141-8.

Goodman MF, Woodgate R. (2000) The biochemical basis and in vivo regulation of SOS-induced mutagenesis promoted by Escherichia coli DNA polymerase V (UmuD $\left.{ }_{2} \mathrm{C}\right)$. Cold Spring Harbor Symp. Quant. Biol.; 65: 31-40.

Grzesiuk E, Janion C. (1994) The frequency of MMS-induced, umuDC-dependent mutations declines during starvation in Escherichia coli. Mol Gen Genet.; 245: 401-15.

Janion C. (2001) Some aspects of the SOS response system - a critical survey. Acta Biochim Polon.; 48: 599-610.
Janion C, Sikora A, Nowosielska A, Grzesiuk E. (2002) Induction of the SOS response in starved Escherichia coli. Environ Mol Mutagen.; 40: 129-33.

Kim SR, Meanhaut-Michel G, Yamada M, Yamamoto Y, Matsui K, Sofuni T, Nohmi T, Omori H. (1997) Multiple pathways for SOS-induced mutagenesis in Escherichia coli: an overexpression of $\operatorname{din} B / \operatorname{din} P$ results in strongly enhancing mutagenesis in the absence of any exogenous treatment to damage DNA. Proc Natl Acad Sci USA.; 94: 13792-7

McKenzie GJ, Magner DB, Lee PL, Rosenberg SM. (2003) The dinB operon and spontaneous mutation in Escherichia coli. J Bacteriol.; 185: $3972-7$.

Miller JH. (1972) Experiments in Molecular Genetics, p 274. Cold Spring Harbor Laboratory Press, Cold Spring Harbor, NY.

Mitchell DL, Nairn RS. (1989) The biology of the (6-4) photoproducts. Photochem Photobiol.; 49: 805-19.

Napolitano R, Janel-Blintz R, Wagner J, Fuchs RPP. (2000) All three SOS-inducible DNA polymerases (Pol II, Pol IV and Pol V) are involved in induced mutagenesis. EMBO J.; 19: 6259-65.

Nowosielska A, Janion C, Grzesiuk E. (2004a) Effect of deletion of SOS-induced polymerases, pol II, IV and V, on spontaneous mutagenesis in Escherichia coli mutD5. Environ Mol Mutagen.; 43: 226-34.

Nowosielska A, Nieminuszczy J, Grzesiuk E. (2004b) Spontaneous mutagenesis in exponentially growing and stationary-phase, umuDC-proficient and -deficient, Escherichia coli dnaQ49. Acta Biochim Polon.; 51: 683-92.

Reuven NB, Arad G, Maor-Shoshani A, Livneh Z. (1999) The mutagenesis protein UmuC is a DNA polymerase activated by UmuD', RecA, and SSB and is specialized for translesion replication. J Biol Chem.; 274: 31763-6.

Schaaper RM, Cornacchio R. (1992) An Escherichia coli dnaE mutation with suppressor 
activity toward mutator mutD5. J Bacteriol.; 174: 1974-82.

Selby CP, Sancar A. (1991) Gene and strand-specific repair in vitro; partial purification of a transcription-repair coupling factor. Proc Natl Acad Sci USA.; 88: 8232-6.

Selby CP, Sancar A. (1994) Mechanism of transcription-repair coupling and mutation frequency decline. Microbiol Rev.; 58: 317-29.

Sutton MD, Walker GC. (2001) Managing DNA polymerases: coordinating DNA replication, DNA repair, and DNA recombination. Proc Natl Acad Sci USA.; 98: 8342-9.

Sutton MD, Smith BT, Godoy VG, Walker GC. (2001) The SOS response: recent insights into $u m u D C$-dependent mutagenesis and DNA damage tolerance. Annu Rev Genet.; 34: 479-97.

Szekeres ES, Woodgate R, Lawrence CW. (1996) Substitution of $m u c A B$ or rum $A B$ for $u m u D C$ alters the relative frequencies of the two classes of mutations induced by a site-specific T-T cyclobutane dimer and the efficiency of translesion DNA synthesis. $J$ Bacteriol.; 178: 2559-63.

Śledziewska-Gójska E, Grzesiuk E, Płachta A, Janion C. (1992) Mutagenesis of Escherichia coli.: A method for determining mutagenic specificity by analysis of tRNA suppressors. Mutagenesis.; 7: 41-6.

Takano K, Nakabeppu Y, Maki H, Horiuchi T, Sekiguchi M. (1986) Structure and function of dnaQ and mutD mutators of Escherichia coli. Mol Gen Genet.; 205: 9-13.

Tang M, Shen X, Frank EG, O'Donnell M, Woodgate R, Goodman MF. (1999) UmuD ${ }_{2}{ }_{2} \mathrm{C}$ is an error-prone DNA polymerase, Escherichia coli pol V. Proc Natl Acad Sci USA.; 95: 8919-24.

Vendewiele D, Borden A, O'Grady PI, Woodgate R, Lawrence CW. (1998) Efficient translesion replication in the absence of Escherichia coli Umu protein and 3'-5' exonuclease proofreading function. Proc Natl Acad Sci USA.; 95: 15519-24.

Vogel HJ, Bonner DM. (1956) Acetylo-ornithinase of Escherichia coli: Partial purification and some properties. $J$ Biol Chem.; 218: 97-106.

Wagner J, Gruz P, Su-Ryang K, Umada M, Matsui K, Fuchs RPP, Nohmi T. (1999) The $\operatorname{din} B$ gene encodes a novel $E$. coli DNA polymerase, DNA pol IV, involved in mutagenesis. Mol Cell.; 4: 281-6.

Wagner J, Etienne H, Janel-Blintz R, Fuchs RPP. (2002) Genetics of mutagenesis in E. coli: various combinations of translesion polymerases (Pol II, IV and V) deal with lesion/sequence context diversity. DNA Repair.; 1: 159-67.

Witkin EM. (1956) Time, temperature and protein synthesis: a study of ultraviolet-induced mutation in bacteria. Cold Spring Harbor Symp. Quant. Biol.; 21: 123-40.

Witkin EM. (1994) Mutation frequency decline revisited. BioEssays.; 16: 37-44.

Woodgate R. (1992) Construction of a umuDC operon substitution mutation in Escherichia coli. Mutat Res.; 281: 221-5. 